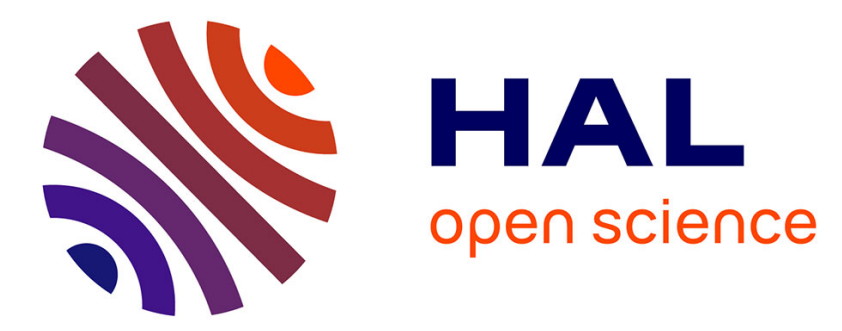

\title{
Patinkin on IS-LM: an Alternative to Modigliani Goulven Rubin
}

\section{To cite this version:}

Goulven Rubin. Patinkin on IS-LM: an Alternative to Modigliani. History of Political Economy, 2004, 36 (Annual supplement), pp.190-216. halshs-00635213

\section{HAL Id: halshs-00635213 https://shs.hal.science/halshs-00635213}

Submitted on 24 Oct 2011

HAL is a multi-disciplinary open access archive for the deposit and dissemination of scientific research documents, whether they are published or not. The documents may come from teaching and research institutions in France or abroad, or from public or private research centers.
L'archive ouverte pluridisciplinaire HAL, est destinée au dépôt et à la diffusion de documents scientifiques de niveau recherche, publiés ou non, émanant des établissements d'enseignement et de recherche français ou étrangers, des laboratoires publics ou privés. 


\title{
Patinkin on IS-LM: \\ An Alternative to Modigliani
}

\author{
Goulven Rubin
}

Whereas Don Patinkin's contribution to the development of the "neoclassical synthesis" is widely acknowledged (D'Autume 2000; Lucas [1980] 1981; Weintraub 1979), his name is generally forgotten when it comes to the history of IS-LM (e.g., see Darity and Young 1995). The aim of this essay is to fill this gap.

To this end, I compare Patinkin's contribution, especially Money, Interest, and Prices (1956), his major work, with that of Franco Modigliani. The representative character of Modigliani's works justifies his choice as the emblematic IS-LM author. Two of his articles need to be considered. The first, a 1944 article, developed the work initiated by John Hicks and set out what became the standard version of IS-LM (De Vroey 2000; Kouri 1986; Leijonhufvud 1994). ${ }^{1}$ The second, a 1963 paper, updated the 1944 model. According to William Darity and Warren Young (1995), this updated model is the apex of IS-LM.

Patinkin's originality lies in his analyzing the IS-LM model with a Walrasian methodology. What Patinkin proposed was actually an alternative to Modigliani's version of IS-LM and, for that matter, a superior model. However, although Patinkin's 1956 book exerted an important

I wish to thank Andres Alvarez, Alain Béraud, and Carlo Benetti for helpful discussions. I am especially grateful to Michel De Vroey for his comments and encouragements. Any error or omission remains my responsibility.

1. “The 'income-expenditure theory' criticized in my 1968 book was, of course, basically the mainstream macroeconomics descended from Hicks' 1937 paper via Franco Modigliani's almost equally influential 1944 contribution" (Leijonhufvud 1994, 147). 
influence, his model was never considered as an alternative to standard IS-LM.

In section 1, I present Modigliani's 1944 paper. In section 2, I show how Patinkin's method allowed him to develop a superior version of IS-LM. In section 3, I consider the content of Modigliani's 1963 paper in order to assess Patinkin's impact on Modigliani's revisions of his prior model. Finally, I come back to the nature of Patinkin's contribution, showing that it formed a bifurcation in the evolution of IS-LM from 1937 to the 1960s.

In what follows, I use the label $I S-L M$ to characterize a set of simplified general equilibrium models sharing a common basic framework. This definition implies that the label $I S-L M$ cannot be restricted to fixedprice models. Such restriction is historically inadequate, since Hicks (1937) assumes flexible prices alongside rigid wages. Actually, three subtypes of IS-LM models should be separated: the market-clearing, or "classical" version, with flexible wages and flexible prices; and two unemployment versions, the first with rigid wages and flexible prices and the second with both wages and prices being rigid.

\section{Modigliani 1944: An Overview}

Modigliani's 1944 paper, "Liquidity Preference and the Theory of Interest and Money," decisively influenced the development of macroeconomics. Its contribution was threefold. First, it recast Hicks's IS-LL model in a new way, allowing for a sharper contrast between its classical and its Keynesian cases. Second, it defended the traditional dichotomy between the real and the monetary sectors and clarified the debate over the determination of the interest rate. Third, it comprised one of the first dynamic analyses of the IS-LM model. I insist on the latter because it reveals a basic defect of Modigliani's approach, the lack of an adequate method to deal with general equilibrium.

\section{IS-LM and the Nature of Keynes's Contribution}

Modigliani's article contained two versions of IS-LM, a market-clearing, or classical, version and a Keynesian one. The main difference between them concerned money wages. In the classical model, both wages and prices were flexible; in the Keynesian model, prices were still flexible 
but money wages were downward rigid. As a result, the Keynesian model comprised two main regimes. If the quantity of money was sufficiently large, wage rigidity was not effective. The Keynesian model behaved like the classical model. If the quantity of money was too low, wage rigidity was effective and the model featured unemployment.

As stressed by Michel De Vroey (2000), Modigliani's contribution represented a crucial step in the evolution from Hicks's 1937 "Mr. Keynes and the "Classics" to the received interpretation of IS-LM. In Hicks 1937, both the classical and the Keynesian models included exogenous wages. The Keynesian theory differed from the classical only when the money demand became infinite, that is, in the liquidity trap case. Hence Hicks concluded that the Keynesian theory was the "economics of depression" instead of a general theory. In contrast, according to Modigliani, Keynes's theory was truly "general," for the Keynesian model included the classical model as a particular case. Moreover, Modigliani $(1944,65)$ claimed that the key aspect of the Keynesian theory was the assumption of downward wage rigidity rather than liquidity preference, for only wage rigidity was sufficient to generate an unemployment equilibrium:

It is usually considered as one of the most important achievements of the Keynesian theory that it explains the consistency of economic equilibrium with the presence of involuntary unemployment. It is, however, not sufficiently recognized that, except in a limiting case to be considered later, this result is due entirely to the assumption of "rigid wages" and not to the Keynesian liquidity preference.

In Modigliani's view, the liquidity trap was only a part of the Keynesian theory. It was an important result, for it showed that the market-clearing model could be deprived of any equilibrium solution: "The very mechanism that tends to bring about full-employment equilibrium in a system with "flexible' wages" could "break down" (74). Nevertheless, this was only an extreme case. ${ }^{2}$

2. It should be noted that there is a gap between Modigliani's definition of the liquidity trap and the trap as derived from his mathematical model. This is the consequence of an error in the formulation of the first versions of IS-LM. Hicks and Modigliani's models determine a money income instead of a real income. Consequently, the aggregate demand curve in their models is of a hyperbolic form $\left(X^{D}=Y / P\right)$. This means that, contrary to Modigliani's statement (our quotation from 1944, 74), if wages are flexible, his model always has a full-employment equilibrium. 
The Defense of the Traditional Dichotomy and the Determination of the Interest Rate

In "Say's Law: A Restatement and Criticism" (1942), Oskar Lange combined Walras's law and a specific definition of Say's law to show that the level of money prices was indeterminate in the classical theory of prices. ${ }^{3}$ In his 1944 article, Modigliani challenged this criticism of the traditional dichotomy of real and monetary economics. According to Modigliani $(1944,69)$, Say's law was not an attribute of the classical system. Rather, the hallmark of the classics was their view that "all the supply and demand functions [except the ones for money] must be homogeneous of zero degree, if people behave rationally" (46). In accordance with the traditional approach, the equations concerning the goods markets determined relative prices, while a monetary equation of the form $M=k P X$ determined the price level. This defense of the traditional dichotomy was reflected in the 1944 market-clearing model $(67-68,71)$. The savings and investment functions were assumed to be homogeneous of degree zero with respect to money prices. This allowed Modigliani to multiply money income by $1 / W$ in each function to obtain the equilibrium condition:

$S(r, P X / W)=I(r, P X / W)$

Since the equilibrium condition for the labor market and the production function determined the level of output $X$ and the real wage $W / P$, this equation determined the rate of interest. The latter being given, the monetary equation determined the money wage, hence the price level:

$M=L[r, W(P X / W)]$

This dichotomy also played an important role in Modigliani's contribution to the debate over the determination of the rate of interest because it generated the conclusion that the interest rate depended only on "real factors" as long as wages were flexible (i.e., it was independent of the quantity of money and of money demand). In contrast, whenever wages were rigid, the rate of interest was simultaneously determined by real and monetary factors, that is, by IS and LM.

3. Say's law, in Lange's definition, states that the sum in value of all excess demands, except the excess demand for money, is identically nil. Walras's law extends this property to the excess demand for money. If both "laws" are valid, it means that an economic system of $n$ equilibrium conditions comprises only $n-2$ independent equations for $n-1$ money prices. 
The Formation of the "Monetary Equilibrium" and the Lack of a General Equilibrium Method

Modigliani called the point of intersection of the IS curve and the LM curve the "monetary equilibrium." He must be credited for having attempted to account for its formation: "We now finally proceed to consider the process by which the equilibrium of the system is established" $(1944,60)$. While this analysis is a noteworthy aspect of Modigliani's contribution, it has often been neglected. ${ }^{4}$ Modigliani's reference was the Marshallian equilibrium theory, an approach conceived to analyze the adjustment in time of a single market, not the interaction between the markets for goods and money.

In the Marshallian approach, a distinction is drawn between the short period equilibrium and the long period, or normal, equilibrium. In the short period, the quantity supplied is given and price adjusts until demand equals supply. In the long period, the quantity supplied varies until no agent wants to modify his behavior. Modigliani $(1944,87)$ attempted to apply this conceptual scheme to the IS-LM model, as explicitly stated in the conclusion of the paper:

As we have shown in our model the equality of demand and supply of loanable funds is the equilibrium condition for the week (or for our income period) and determines the equilibrium rate of interest (or system of rates) for the week. It corresponds to the short-run equilibrium condition of the Marshallian demand and supply analysis: price equals marginal cost. But the stock of money to hold (the supply) tends itself to change and thus to push the daily rate towards the level at which the flow of money saving equals the flow of money investment. The condition (ex ante) saving $=($ ex ante $)$ investment, corresponds to the long-run Marshallian condition (under perfect competition): price $=$ average cost including rent.

In order to apply the Marshallian short period equilibrium concept to the IS-LM model, Modigliani introduced a separation between the transaction demand for money and the speculation demand for money. The former depended on money income only, the latter on the rate of interest only. Given this separation, Modigliani reformulated the LM relation

4. See, for instance, Darity and Young 1995. An exception is offered by P. J. K. Kouri (1986, 313), who notes that "the second contribution of [Modigliani's] article was an explicit analysis of the short-run dynamics of the Keynesian model." 
as $S_{a}=D_{a}$ where $S_{a} \equiv M^{s}-D_{T}(Y)$ was the "supply of money to hold" and $D_{a} \equiv D_{a}(r)$ was the "demand for money to hold." Moreover, Modigliani defined the adjustment process toward the "monetary equilibrium" as a sequence of "income periods." In each income period, agents decided how to use the income inherited from the preceding period. The variable $Y$ in the behavior functions was given within the income period. As a result, $S_{a}$ was fixed. Modigliani further assumed that the rate of interest varied until the demand for money $D_{a}$ equaled the supply $S_{a}$. Thereby, the money market equilibrium became tantamount to the Marshallian short-period equilibrium.

As to the "monetary equilibrium," suppose, said Modigliani, that for a given money income, the rate of interest that equilibrates $S_{a}$ and $D_{a}$ does not equilibrate savings and investment. A process of adjustment was triggered. The supply of money to hold would change from one period to the other until savings equaled investment. The latter was viewed as tantamount to the Marshallian long-period equilibrium condition.

Unfortunately, Modigliani's use of short-period and long-period equilibrium was beset with ambiguities. First, Modigliani's specific use of the Marshallian method turned the IS schedule into an expression of the state of the money market. That is, LM defined the short-run equilibrium of this market, IS its long-run equilibrium. "For this purpose we must once more revert to the money market which we must, this time, consider in terms of flow rather than in terms of stocks" $(1944,60)$. So, according to Modigliani, IS reflected the state of the money market in terms of flows. ${ }^{5}$

Conversely, Modigliani never mentioned the goods market in relation to IS. Now, if IS was nothing but a reflection of the money market, IS-LM was no longer a general equilibrium model. Put differently, the "monetary equilibrium" was not the simultaneous equilibrium of two different markets (goods and money), but the equilibrium of a single market (money) in the short run and in the long run.

A second problem facing Modigliani's approach was the discrepancy that arose between his formalization of the mechanism adjusting savings and investment, and his verbal account of it. It comes out very clearly when looking at how Modigliani wrote down the dynamic version of his model in section 10 of his paper:

$Y_{t}-Y_{t-1}=I_{t}\left(r_{t}, Y_{t-1}\right)-S_{t}\left(r_{t}, Y_{t-1}\right)$

5. "There are two ways of looking at [the money market]: (a) in terms of flows (savings and net borrowing) and (b) in terms of stocks" (1944, 54; emphasis added). 
Money income was supposed to diminish discretely as long as savings exceeded investment. However, when describing the formation of the "monetary equilibrium" and in commenting on his dynamic model, Modigliani never referred to this mechanism. To wit, here is how he presented "the process by which the equilibrium of the system is established": "If net savings exceeds net borrowing then, on balance, the supply of money to hold will increase above the level of the previous period, say $\mathrm{D}_{\mathrm{a} 0}$. But at the old rate of interest $\left(\mathrm{r}_{0}\right)$ people will not want to hold extra supply; they will therefore try to purchase securities and thus will lower the rate of interest" (61).

Modigliani's reasoning was globally correct. If savings exceeded investment at the equilibrium rate of interest of period one, the supply of money to hold would exceed the demand of money to hold in period two. The missing link was that Modigliani should have said that excess savings in period one triggered a fall in money income. Consequently, the transaction demand for money declined in period two and $S_{a}$ increased. Oddly enough, Modigliani never mentioned this mechanism. A possible explanation is that the status of money income as an adjustment variable of the money market was quite difficult to justify.

In short, Modigliani's paper lacked an adequate method to deal with a general equilibrium.

\section{Patinkin's Money, Interest, and Prices}

In Money, Interest, and Prices (1956), Patinkin presented two macro models, a market-clearing and a market-nonclearing one, without making clear their relation to IS-LM. ${ }^{6}$ Nonetheless, some evidence exists suggesting that they derived from this apparatus. For what concerns the fixed-price model (1956, chap. 13, sec. 4), Patinkin indicated in 1990 that "the interpretation presented in chapter XIII: 4 and XIV: 1 and 3 of the 1956 and subsequent (1965 and 1989) editions of my Money, Interest and Prices is essentially that of IS-LM" $(1990,213)$. In contrast, he never used the label $I S-L M$ to characterize his market-clearing model. Yet the titles of the chapters of Money, Interest, and Prices in which Patinkin presented his macro models, "The Workings of the Model: Full Employment" and the "Workings of the Model: Involuntary Unemployment," suggest that they were subtypes of a broader apparatus. Moreover,

6. He alludes to IS-LM only once to point to the parallel between one of his diagrams (1956, 226) and Hicks's 1937 diagram. 
the idea that the basic structure of Patinkin's "full employment" model was essentially that of IS-LM is supported by this assertion taken from a paper preceding the publication of Money, Interest, and Prices: "This model is essentially Keynesian in nature, in so far as its basic components are an aggregate demand function and a liquidity-preference function which depends upon the rate of interest" $(1954,124)$.

These elements support the claim that Patinkin borrowed the skeleton of his macro models from Hicks and Modigliani. The originality of his contribution stemmed from its outright Walrasian inspiration. The result of this "Walrasation"7 of IS-LM was a superior apparatus, for, as I now want to show, Patinkin's version of IS-LM was clearer and more consistent than Modigliani's 1944 model.

\section{Patinkin's Method}

As the subtitle of Money, Interest, and Prices indicated, Patinkin's aim was to integrate "monetary and value theory." This aim was pursued both at the microeconomic level (part 1 of the book) and at the macroeconomic level (part 2), but its meaning differed slightly in each case. At the microeconomic level, the subject of analysis was the Walrasian model of a pure exchange economy. At the macroeconomic level, the subject of analysis was IS-LM, but IS-LM developed and analyzed as if its foundations could be derived from the Walrasian theory. For Patinkin, this attempt to make macroeconomics consistent with the Walrasian theory of prices was a necessary aspect of the "integration of monetary and value theory" because for him IS-LM belonged to monetary theory. ${ }^{8}$

Three basic ideas, all drawn from the Walrasian theory, underlie Patinkin's method. First, a general equilibrium model represented a market system or a set of interrelated markets. This meant that each market should be represented by a set of equations in the model and that each equation of the model should refer to a specific market. In this context, the term market simply referred to the fact that a certain good had a demand, a supply, and a price.

Second, goods were demanded and supplied by agents whose behavior was bounded by the discipline of the Walrasian budget constraint.

7. This expression is borrowed from De Vroey 1999a.

8. In Patinkin's language, "monetary theory" comprised the quantity theory of money and Keynes's unemployment theory, hence classical and Keynesian macroeconomics (cf. the title of Patinkin's 1976 essay about the genesis of the General Theory: "Keynes' Monetary Thought"). 
This constraint stated that, prices being given, the value of agents' spendings should always equilibrate the value of their resources. The budget constraint was unique, which meant that each agent decided simultaneously what his or her demands would be on all the markets of the economy. Walras's law, stating that, whatever the vector of prices, the sum in value of all market excess demands was identically equal to zero, could be derived from the aggregation of all budget constraints.

Third, Patinkin considered that assessing the logical existence of general equilibrium was insufficient. The issue of its formation also had to be addressed. This was the role played by the Walrasian tâtonnement. The tatonnement was primarily a representation of how "a free market economy finds its way towards the equilibrium position" $(1956,36)$. In this respect, it implied a set of assumptions (the metaphorical auctioneer, the recontracting assumption) ensuring that it "necessarily brings the economic system to that same set of prices yielded by a direct mathematical solution of the system of excess-demand equations" (378). But tâtonnement was also the "method of successive approximation" (32, 152) enabling the theorist to decompose the process of adjustment of the market system. This method was based on the general application of the law of demand. Any disequilibrium on one market triggered an equilibrating variation of the price on this market. Yet it also impinged on the state of other markets. Variations of other prices were induced that would, in turn, react on the initial market.

\section{IS-LM as a Market System}

Contrary to Modigliani, Patinkin defined explicitly his model as the representation of a market system. Yet, as is normal in a macroeconomic perspective, the numerous markets of microeconomics were reduced to a small number of representative markets: "In particular we forego microeconomic detail and work instead with an aggregative model which divides all the goods of the economy into four composite categories: labor services, commodities, bonds and money. To each of these categories there corresponds a market, a price, an aggregate demand function and an aggregate supply function" $(1956,125)$. As a consequence of this general approach, Patinkin replaced the savings-investment equation by an equation relating the demand and the supply for commodities. Admittedly, this modification was minor insofar as both equations were equivalent (chap. 11, sec. 6). Still, it eliminated the ambiguity surrounding 
IS in Modigliani's paper. "This decision has been based on the fact that such a concept [savings] is out of place in an analytical framework which views the economy as consisting of a number of goods, each with a price, and each with a market. For savings are clearly not a good, they have no price, and they are not themselves transacted on a market" (186).

Following the same logic, Patinkin introduced explicitly the bonds market in his macroeconomic model. The model then appeared as a system of four equilibrium equations with three unknowns:

$\mathrm{N}^{\mathrm{S}}\left(\frac{W}{P}\right)=\mathrm{N}^{\mathrm{D}}\left(\frac{W}{P}\right)$
$\mathrm{X}_{\mathrm{fe}}=\mathrm{F}\left(X_{f e}, r, \frac{M}{P}\right)$

$\mathrm{B}^{\mathrm{S}}\left(X_{f e}, r, \frac{M^{F}}{P}\right)=\mathrm{B}^{\mathrm{D}}\left(X_{f e}, r, \frac{M^{H}}{P}\right)$

$\mathrm{M}=\mathrm{P} \cdot \mathrm{l}^{\mathrm{D}}\left(X_{f e}, r, \frac{M}{P}\right)$

Next, using Walras's law and a set of simplifying assumptions related to the labor market, Patinkin showed how his four-equations model could be reduced to the interaction between two different markets (goods and bonds or goods and money).

Thereby he was able to avoid Modigliani's tortuous concept of "monetary equilibrium." The general equilibrium of the "full employment" macro model was simply the situation in which prices were such that demand equaled supply on each market. Patinkin used Walras's law to show that the system contained only three independent equations for three unknown variables and explained that he took "this equality between the number of equations and unknowns as justifying the reasonableness of the assumption that this system of equations does have a solution" (152).

\section{Tâtonnement and the "Working" of the Model}

The use of Walras's law and of the tâtonnement device allowed Patinkin to account verbally for the adjustment process leading to equilibrium in the various versions of the IS-LM model. 
The tatonnement method was perfectly appropriate for the analysis of the market-clearing model. Like Modigliani, Patinkin conducted a thought experiment. He defined a situation in which the goods market was in equilibrium but the bonds market was in excess demand. Next, with the help of the law of demand and supply, he showed how this situation resulted in a process of interaction between the two markets. The disequilibrium on the bonds market induced an adjustment of the price for bonds. This adjustment had a stabilizing influence on this market yet a destabilizing influence on the goods market; that is, the rate of interest fell so that aggregate demand for goods rose. This new disequilibrium on the goods market induced a fall of the price level, which had a stabilizing effect on both the goods and the bonds markets. These forces were assumed to bring the system back toward general equilibrium. ${ }^{9}$

Patinkin also used the tâtonnement approach for his market nonclearing model. If a disequilibrium on the goods market was assumed to induce a variation of the price level, how could one account for the fact that income became the adjustment variable in the model with unemployment? This was the question addressed in chapter 13 of Money, Interest, and Prices. According to him, some impediment on the adjustment of aggregate demand toward its market-clearing level was needed. In these conditions, firms eventually adjusted production, hence income, to the level of aggregate demand whatever the level of real wages. Patinkin $(1956,225)$ offered a formal representation of this situation in the "extreme" case where prices and wages were "absolutely rigid." The functioning of this model was analyzed just like the functioning of the market-clearing model, using the "tâtonnement" method, income replacing the price level as the adjustment variable for the goods market. Patinkin stressed the connection between his analysis and the IS-LM analysis of Hicks and Modigliani, neglecting the fact that in their models only wages were rigid, while both prices and wages were fixed in his own model. 10

9. Of course, Patinkin did not go far enough in the verbal exposition of his experiment. The first reason for this was that an exhaustive description of the evolution of the varying combinations of forces at work during the adjustment process and of their possible effects on the two markets would rapidly have become too tedious. Hence Patinkin borrowed from Metzler 1951 a graphic apparatus similar to Hicks's IS-LM graphic but designed for the full-employment case. And since this phase diagram hardly provided a proof of stability, in his "mathematical appendix" Patinkin eventually proceeded to analyze algebraically the conditions for stability of a dynamic version of his model.

10. According to Patinkin, the Keynesian theory had to demonstrate that a perfectly competitive system with price and wage flexibility could suffer from chronic unemployment. Hence its 
Patinkin's method also clarified the adjustment mechanism of the "rigid wage-cum-flexible price" IS-LM model. In such a framework, the price level was the adjustment variable of $X^{D}$ and $X^{S}$, hence of $I$ and $S$. An excess demand for goods induced a fall of prices, the real wage increased, and the desired aggregate supply for goods decreased until $X^{S}=X^{D}(1956,223-24)$. This analysis ran counter to Modigliani's claim that income was the adjustment variable for the goods market. This was true only when prices as well as wages were "absolutely rigid."

False Dichotomy, Monetary Illusion, and the Real Balance Effect

Another improvement made by Patinkin was his correction of a contradiction involved in Modigliani's full-employment model, a particular instance of the "false dichotomy" between the real and the monetary sector.

Patinkin (1947, 1949a, 1956) generalized Lange's criticism by showing directly, that is, without reference to Say's law, that the assumption of zero-degree homogeneity was inconsistent with the use of the Cambridgian monetary equation. The key of his demonstration was Walras's law. If all market excess demands, save the excess demand for money, were homogeneous of degree zero with respect to the price level, the excess demand for money should also share this property because of Walras's law. This was in contradiction with the specification of the traditional monetary equation $(M=k P X)$, which stated that the excess demand for money was not homogeneous with respect to $P$. As soon as the ISLM model was considered as a system of interrelated markets consistent with Walras's law, Patinkin's criticism applied. Modigliani claimed that only the excess demand for money was not homogeneous of degree zero. Therefore, it had to be inferred that the excess demand for bonds was also homogeneous of degree zero. In this case, Modigliani's

object was "the dynamic workings of an economy in disequilibrium" (Patinkin 1956, 224; on the origin of this aspect of Patinkin's thought, see Rubin 2002a and 2002b). Obviously, IS-LM was not an appropriate vehicle for this conception. Patinkin thus developed an interpretation of the fixed-price version of IS-LM in accordance with his interpretation of the theory of involuntary unemployment. Either it was a limiting case of the Keynesian theory, as in Money, Interest, and Prices (chap. 13, sec. 4), or it was the reflection of the state of an economic system in disequilibrium at a point in time. It was like a snapshot of the economy during its adjustment process. Prices were given but not rigid. They were bound to change under the pressure of disequilibrium on the markets for goods and labor. This last interpretation appeared in later works (Patinkin 1974, 1990a, and 1990b). 
monetary equation (equation [6] above) was inconsistent with his equilibrium conditions for the labor and the goods market and with his implicit equation for the bonds market.

Patinkin also provided a solution to the indeterminacy of the price level in the Walrasian model through the introduction of real balances in the excess demand functions. The key concept in this respect was the Walrasian budget constraint. In a monetary economy, agents held money balances. Insofar as they acted in accordance with their budget restraints, any variation of the price level had to affect their expenses. A price increase reduced the real value of their money balance. Therefore, the demands for goods, bonds, and money had to decrease. This real balance effect still existed in the aggregate if money was a net wealth for the economic system as a whole or if the value of money balances was not canceled by the value of some private debts (Patinkin 1948, 550).

Real demand functions were now homogeneous of zero degree with respect to $P$ and $M$. Therefore the inconsistency affecting Modigliani's classical model disappeared. The classical dichotomy between a real sector and a monetary sector also vanished, yet the neutrality of money could still be demonstrated. In the context of a system with price and wage flexibility and no distribution effects, this result depended only on the absence of monetary illusion (Patinkin 1954, 1956).

The Debate over the Determination of

the Rate of Interest

Patinkin's introduction of the bonds market clarified the debate over the determination of the interest rate. For Modigliani, the issue was whether the rate of interest was determined by IS or by LM. Patinkin's general equilibrium approach showed how irrelevant this issue was. The rate of interest was primarily related to the bonds market, since it was the reciprocal of bonds' price. Nonetheless, like all prices, it was generally determined simultaneously by all the equations of the model. Hence the determination of the rate of interest by IS was necessarily due to some special assumptions implicitly made by Modigliani, namely, the absence of real balance effect on the goods market.

\section{The Liquidity Trap}

According to Hicks (1937), Lange (1938), and Modigliani (1944), the liquidity trap was the consequence of an infinite money demand. This 
definition was based on an "individual-experiment," to borrow Patinkin's expression $(1956,15)$. To check its validity, it was necessary to examine how an isolated agent reacted to a change in the rate of interest. Hicks, Lange, and Modigliani all assumed that when the rate of interest reached a certain value, "individuals" money demands became infinite. This feature no longer held when the budget constraint was brought into the picture. Assuming that agents respected their budget constraints, an infinite money demand required infinite resources. The only possible source of such infinite resources was an infinite bonds supply: "But an individual who plans an infinite supply of bonds is for some reasons unconcerned with his obligation to make interest payments on these bonds. Hence if the amount supplied is infinite at any positive rate of interest, it must be so at all rates. Under this assumption, it follows that the demand for money would also be infinite at all positive rates" $(1956,149)$. In other words, Hicks's definition of the liquidity trap amounted to the assumption that agents did not respect their intertemporal budget constraints. Conversely, if this constraint was to hold, the liquidity trap could not be the consequence of an "individual-experiment."

Next, Patinkin showed that this phenomenon could still appear as a "market experiment," that is, as the result of the interaction between different individuals on the marketplace. The form of the demand for bonds was decisive here. Suppose that the aggregate demand for bonds became nil when the rate of interest reached a low value. As soon as this low value was reached, any increase in the money supply could no longer finance an increase in the demand for bonds, for this demand was nil. If, in addition, it was supposed that agents did not spend any additional real balances on the goods market (i.e., if there was no real balance effect on the goods market), then the only effect of this increase would be an increase in money demand. In these conditions, an infinite increase in money supply would finance an infinite increase of money demand (Patinkin 1956, 245-49). This implied that an LM curve built on the assumption of a constant money supply could not present a flat portion. In the $(r, X)$ space, the phenomenon of the liquidity trap would be reflected by the curve expressing the equilibrium condition for the bonds market rather than by the shape of the LM curve. Beyond a certain amount of money supply, this curve would appear as a horizontal straight line and define a minimum rate of interest. 
Walras's Law and Unemployment

The final important clarification introduced by Patinkin that I want to discuss concerns the use of Walras's law. The latter was implicitly invoked by Modigliani to justify the exclusion of the bonds market from IS-LM analysis. ${ }^{11}$ Yet if this procedure was perfectly correct in the case of a market-clearing model, it became problematic when applied to a model with unemployment. Patinkin was the first to raise this issue in a 1958 paper titled "Liquidity Preference and Loanable Funds: Stock and Flow Analysis."

In this paper, Patinkin analyzed an unemployment equilibrium model based on fixed prices and wages. Unemployment equilibrium meant that the labor market was in excess supply, whereas the markets for goods, bonds, and money were in equilibrium. Such an outcome contradicted Walras's law as defined by Patinkin at the beginning of his paper: "If any $\mathrm{n}-1$ excess-demand equations are satisfied, the remaining one must also be satisfied" (300), hence the remark that "at first sight, then, there would seem to be no place for the operation of Walras" law" (314).

Clearly, such a result was hardly acceptable for Patinkin, since Walras's law was a basic instrument of his analysis of the fixed-price version of IS-LM. For instance, it allowed him to state that "the curve MM [or LM] must, of course, also pass through the points" (1956, 229), the point of intersection of his IS curve and of the curve expressing the locus of all equilibrium in the bonds market. Likewise, in his 1958 paper, Patinkin used Walras's law to show that there was no difference between a theory of interest based on the equation for bonds (a "loanable funds theory") and a theory based on the money equation (a "liquidity preference theory"). In order to extend this conclusion to the case of involuntary unemployment, he had to show that Walras's law applied in this case, too.

Patinkin's escape consisted of modifying the households' budget constraint. Drawing from the idea that in a situation of involuntary unemployment workers' incomes were determined by firms' labor demands, he substituted $N^{D}$ for $N^{S}$ in the household budget constraint: "The righthand side of the household account reflects our assumption that wage earners passively expect to receive whatever employers plan to pay; hence the term $\mathrm{N}^{\mathrm{D}}$ appears there as well as on the left-hand side of the

11. "Without the benefit of that crutch, in my 1944 paper I was led in the formal model of section 2, to drop any explicit reference to the bond market-implicitly treated as the redundant one" (Modigliani 1944, 81). In the text preceding this note, the notion of "redundant market" was related to "Walras' law." 
business account" $(1958,315)$. As a result, the aggregation of agents' budget constraints yielded a modified Walras's law that was restricted to three markets: the markets for goods, bonds, and money. This relation could then be used to analyze the unemployment versions of IS-LM.

To conclude this section, my above analysis clearly indicates that Patinkin's model was more consistent than Modigliani's 1944 IS-LM model. In the main, the framework of Patinkin's macro model was basically similar to Modigliani's: a four-market system with the same simplifying assumptions to deal with the labor market; the same treatment of expectations; aggregate demand split in two components, consumption and investment; a liquidity preference function; and a market for bonds. But Patinkin's use of the Walrasian method clarified the properties of the system. Moreover, as seen, it eliminated many of the inconsistencies of Modigliani's article. What remains to be studied is the fate of Patinkin's version of IS-LM.

\section{Modigliani's Monetary Mechanism}

Modigliani's 1963 article, "The Monetary Mechanism and Its Interaction with Real Phenomena," is an updated version of his 1944 model examining its implications for monetary theory and for economic policy. Modigliani refers to that model as a "Mid-50's model" and says it is "essentially the model that I would have used had I been writing a comparable article at that time (and did actually use in my class lectures)" $(1963,79)$. My purpose here is to assess Patinkin's influence on Modigliani's revised model.

In the first part of his paper, Modigliani listed five modifications introduced in his 1963 model and distinguishing it from his 1944 model: (1) "explicit reliance on a general equilibrium formulation"; (2) "explicit treatment of the bond market" and introduction of a private banking sector; (3) "improvements in the consumption and investment functions"; (4) "correction of the faulty formulation of the homogeneity properties of the consumption, investment and demand for money functions"; and (5) "use of a more convenient and effective device for expressing the hypothesis of wage rigidity." Patinkin's influence is obvious for several of these modifications. As far as the first is concerned, the "explicit reliance on a general equilibrium formulation" $(1963,80)$ was a novelty whose definition paraphrased the introduction of chapter 9 of Money, Interest, and Prices $(1956,125)$ : “The mid-fifty model is explicitly structured in 
terms of markets, one for each commodity, with each market in turn described by (a) supply conditions, (b) demand conditions, and (c) clearing of market or equilibrium conditions, of which one is redundant (Walras' law)" (1963, 80-81). Thus, Modigliani adopted Patinkin's idea that a general equilibrium model represented a market system. The "explicit treatment of the bond market" (81) was also borrowed from Patinkin. The same was true for the "correction of the faulty formulation of the homogeneity properties of the consumption, investment, and demand for money functions" (82). The assumption that "the real demand for consumption, investment, and money is homogeneous of zero degree in money income, wealth, and prices" and the fact that "this property is an implication of rational behavior" (82) were the results of Patinkin's investigations.

Modigliani's new formalization of wage rigidity $(1963,82)$ must also be viewed as an indirect consequence of Patinkin's criticisms. In 1944, Modigliani associated wage rigidity with the assumption of a horizontal supply curve of labor. Patinkin $(1947,1949 b, 1956)$ had shown that this was an unsatisfactory representation of involuntary unemployment, because workers were always "on their supply curve of labor." Modigliani was well aware of this criticism, having read Patinkin's PhD thesis, in which it was already present. Furthermore, Patinkin expressed this criticism in a letter addressed to Modigliani in April 1948.12 Modigliani's abandonment of the "horizontal supply curve of labor" must thus be interpreted as having been prompted by Patinkin. This explains Modigliani's insistence on the fact that "the difference between this level of employment [determined by $N^{D}$ ] and the potential supply at $\mathrm{W}_{0}$ is then 'involuntary unemployment' in the Keynesian sense" $(1963,82)$.

The two modifications not inspired by Patinkin were of more secondary importance. The first was the introduction of a private banking sector in the model. The second consisted in "improvements in the consumption and investment function and in particular more adequate recognition of the role of stocks" (81). The latter "improvements" were the introduction of aggregate labor income $N W / P$ in addition to real income $X$ in the consumption function and the introduction of the stock of capital $K_{0}$ in the investment function. Yet both variables were actually neglected in the subsequent analysis. The introduction of a banking sector did not modify the basic structure of the model. Though a useful

12. An analysis of Patinkin's position on this point and of the problems raised by the "horizontal supply curve of labor" is presented in Rubin 2002a. 
refinement, it was hardly new in 1963 after Gurley and Shaw 1960 and Patinkin 1961.13

In sum, the modifications of the 1944 model resulted in a set of equations nearly identical to the equations of Patinkin's model. There is, however, one topic on which Modigliani refused to accept Patinkin's viewpoint, the issue of the dichotomy between the real and the monetary sector. Modigliani persisted in defending his own definition of this dichotomy. To him, Patinkin's conclusion concerning the neutrality of money was erroneous: "We proceed first to a summary of some implications of the model within the classical framework of price and wage flexibility. Its main justification is the hope of disposing for good of a controversy, connected with the names of Pigou and Patinkin, which has plagued the profession, draining the resources into what strikes me as a largely barren endeavor" (Modigliani 1963, 83).

In terms of these definitions, Patinkin's basic contention could be summarized as follows: "In an economy relying on a token money as a medium of exchange, the dichotomy does not hold, but under certain conditions money will be neutral. . . It is found that Patinkin's contention is basically unwarranted, although no attempt at rigorous proof is possible here" (84).

To substantiate his claim, Modigliani analyzed three cases. The first was a model with pure bank money or internal money, the second a model with government money and no public debt, and the third a model with public debt. Since in the first case the classical dichotomy was valid and since in the third money was not neutral, Patinkin, he claimed, was wrong. This criticism is hardly convincing, since it actually boils down to a summary of different results that could be derived from Patinkin's model. That money was not neutral when public debt was introduced was explicitly recognized in Money, Interest, and Prices (1956, 207). The case of a system with pure bank money was not analyzed in that edition. Distribution effects being absent, a variation of $P$ does not affect the goods market, for the resulting variation in the aggregate value of real money balances is offset by the losses of bank debtors. If, moreover, full employment is assumed, the rate of interest is determined by the condition of equilibrium on the goods market so that "the equilibrium value of the real variables of the system is independent of both the

13. In the first edition of Money, Interest, and Prices, Patinkin explicitly excludes the banking sector from his analysis, assuming that money is only composed of government money (cf. 1956, 145, 206 n. 17). 
supply and the demand for money" (Modigliani 1963, 84). In this context, Modigliani's definition of the dichotomy proves valid. Moreover, in the absence of real balance effect, the model could contain a liquidity trap. In the second edition of Money, Interest, and Prices, Patinkin ([1965] 1972, 331) admitted the logical validity of Modigliani's analysis of the pure bank money case. Nevertheless, he hardly considered it an invalidation of his own conclusions concerning the dichotomy and the neutrality of money. Modigliani showed that, if some of Patinkin's 1956 assumptions were removed, his 1944 conclusions held good. In this sense, his analysis was only an extension of Patinkin's work. However, by Modigliani's own standards, his assumptions were extreme. To get a model with no real balance effect, he had to assume that the economy had no central bank and no public debt. For, like Patinkin and most authors of the neoclassical synthesis, Modigliani considered that money supplied by the government, or by a central bank, and government bonds were net wealth. ${ }^{14}$ Obviously, the model he put forward had only a limited utility. 15

Modigliani's argumentation about dichotomy and the neutrality of money shows that much of his 1963 paper should be viewed as an answer to Patinkin, yet all in all, Modigliani's very efforts to evade Patinkin's conclusions illustrate the rigor and scope of Patinkin's model.

The conclusion can then be drawn that Modigliani's updating of his 1944 model was inspired by Money, Interest, and Prices. However, Modigliani stopped short of adopting the Walrasian dimension of Patinkin's approach. In particular, he left aside the Walrasian budget constraint and the tâtonnement process.

While mentioning Walras's law, Modigliani was wanting in his consideration of the budget constraints of agents. His analysis of the classical model $(1963,85)$ suggests that he considered the decisions of each agent as a set of separate optimization programs, each with its specific constraint. Households made a decision concerning their labor supply, then they decided how much of their income to save, and, finally, they determined the level of their demand for money or the composition of

14. Indeed, Modigliani (1987) was very critical about Robert Barro's Ricardian equivalence theorem (Barro 1974). Yet, ironically, this theorem is the strongest argument to support the idea that there is nothing else but "inside money" or that the "pure bank money case" is the general case.

15. To discuss the "role of government monetary and fiscal operation" (1963, sec. 4, 93), Modigliani had to integrate government money and government debt in his model. 
their portfolio. This loose treatment of microfoundations hardly differs from his approach in the 1944 paper (48-54). Actually, the latter was more explicit.

No reference to the formation of equilibrium is to be found in the 1963 article. While Modigliani abandoned his 1944 analysis of the short and long periods, he did not adopt the tâtonnement method. The way Modigliani uses the word force in his paper illustrates the contrast between his approach and Patinkin's. In physics, a force is the cause of movement. By analogy, in Money, Interest, and Prices, the "market force" is the pressure an excess demand on one market exerts on the price of this market. This "force" is thus the immediate cause of price variations. It is a precise dynamic concept used to analyze the formation of equilibrium. In Modigliani's 1963 paper, the word force carries the same dynamic connotations. Yet its use is actually inappropriate, since the related analysis is purely static: "It may be useful to state in plain English the major forces determining equilibrium in the system described by Model II under the stated assumptions. This mechanism can be summarized roughly as follows ..." (85). The words forces and mechanism in this passage seem to announce a dynamic analysis. Yet eventually the "forces determining equilibrium in the system" turn out to refer to the parameters lying behind the equilibrium conditions of Modigliani's model, the "initial stock of capital," the "preferences for current and future consumption as compared with leisure," and so on, rather than to forces in the strict sense. This loose utilization underlines Modigliani's lack of a definite way to deal with the formation of equilibrium. Some isolated fragments of dynamic analysis further illustrate how distant he is from Patinkin in this respect. For instance, when dealing with his market-clearing model with government debt, Modigliani $(1963,87)$ states that "an increase in the money supply by increasing $\mathrm{P}$ and reducing real wealth, will tend to increase saving and reduce the rate of interest to the extent necessary to produce a matching increment in investment." In contrast to Patinkin's tâtonnement approach, this piece of analysis implies that the price level is the adjustment variable on the money market (rather than on the goods market), and the rate of interest the adjustment variable on the goods market (rather than on the bonds market). Instead of reasoning in terms of well-defined markets and of behavior functions, Modigliani manipulates rather mechanically, though correctly, his IS and LM equations. A last example of the difference between Modigliani and Patinkin is Modigliani's adoption of a 
markup pricing $(1963,91)$. The assumption of markup pricing is clearly incompatible with a tâtonnement setting in which agents are assumed to be price takers.

Two points have been made in this section. I have shown that Modigliani's "Mid-50's model" was strongly influenced by Patinkin. However, it must also be realized that Modigliani did not fully rally behind Patinkin's standpoint. In particular, he stopped short of adopting two basic features of the Walrasian approach, the budget constraint and the $t \hat{a}-$ tonnement method.

\section{A Bifurcation That Was Not Taken}

My above analysis runs counter to the standard conception of the history of IS-LM as a steady accumulation of knowledge beginning in 1937 and culminating in the 1960s. Patinkin's general equilibrium method significantly contributed to the advancement of the standard model. However, if the accumulation story were right, Patinkin's model should have replaced Modigliani's 1944 model as the referential version of IS-LM. This did not happen. The right perspective to adopt, then, is Axel Leijonhufvud's, when proposing to consider the history of economics as forming a decision tree. ${ }^{16}$ In this perspective, Patinkin's work should be viewed as having opened a methodological bifurcation, proposing a Walrasian way to practice general equilibrium analysis as an alternative to Modigliani's Marshallian way. Yet, oddly enough, that bifurcation was not perceived as such and hence remained unexploited. ${ }^{17}$

An in-depth analysis of Modigliani's 1944 paper shows that his approach was non-Walrasian (in the radical sense of this modifier). True, in the beginning of his article, he referred to the Walrasian system as the "only rigorous procedure" to deal with general equilibrium. Yet he soon discarded it as "cumbersome and not well suited to an essentially literary exposition" (1944, 46). No sign of any Walrasian inspiration is present in the remainder of his article. As seen above, whenever Modigliani faced a difficulty, the solution he proposed was Marshallian. Marshallian traits are less present in the 1963 paper, yet the lack of any reference to the

16. "It is useful to think of the history of our subject as forming a decision tree. Major economists force their contemporaries to face choices-choices of what to ask, what to assume, what to regard as evidence and what methods and models to employ-and persuade the profession or some faction of it to follow the choice they make. The path that any particular school has followed traces a sequence of such decisions" (Leijonhufvud 1994, 148).

17. Cf. De Vroey 1999a, 1999b, and this volume. 
tâtonnement and to the Walrasian budget constraints suggests he was not more Walrasian than in $1944 .{ }^{18}$ In other words, the Walrasian theory was actually alien to Modigliani's IS-LM. These elements are consistent with the fact that IS-LM was a general equilibrium model inspired by the General Theory and therefore rooted in the Marshallian school of thought.

In this context, Patinkin's approach marked a breach with Modigliani's conception of IS-LM. Whereas Modigliani developed IS-LM without trying to relate its structure to a fully articulated general equilibrium theory, Patinkin aimed at founding his model in the Walrasian general equilibrium theory. The difference between their respective attempts was more than just a matter of degree. A difference in research programs was involved. The program derived from Modigliani aimed to extend the scope of IS-LM (open economy, Phillips curve, macroeconometric applications) and to deepen the understanding of its components (the consumption function, the investment function, etc.) while keeping them insulated from each other. The emphasis was put on the pragmatic applications of IS-LM. Instead, Patinkin's method called for a synthesis between the macroeconomics inspired by the General Theory and the Walrasian theory of price, with the emphasis put on the logical consistency of the general apparatus. As I have shown in section 3, Patinkin was not followed by the economists of his generation. IS-LM did not become the Hicks-Modigliani-Patinkin model, and the research program of the "neoclassical synthesis" remained the Modigliani program.

These remarks are made in hindsight for the protagonists of this story, and, in particular, Patinkin did not see the matter as I do. While Patinkin opened a new bifurcation on the economic theory decision tree, he did it unwittingly. His lack of awareness persisted over time as two subsequent papers, published in 1990, testify to. The most noticeable, presented at a conference for the fiftieth anniversary of Hicks's model (Patinkin 1990a), was titled "In Defence of IS-LM." Patinkin contended that IS-LM was, first, a "valid representation of the General Theory" and, second, a "useful analytical construct." Patinkin (1990b) developed the same theme when examining critically various post-Keynesian interpretations of Keynes. These two texts show that Patinkin ranked himself among the promoters of the IS-LM model. Yet, above all, they buttress how much he

18. A Marshallian reference appears when Modigliani $(1963,89)$ states that he derives a "relation between P/W and X, which represents in essence the Marshallian short-run supply function for commodities (short run because $\mathrm{K}_{0}$ is fixed)." 
underestimated the distance between the version of IS-LM in Money, Interest, and Prices and the standard version. Only one difference between them is mentioned in these papers, namely, that Modigliani considered a rigid wages-cum-flexible-prices model featuring a "permanent" or "long-run unemployment equilibrium," while his own model was a fixed-price model, the equilibrium of which was interpreted as a "Marshallian short-run unemployment equilibrium" (1990a, 125; 1990b, 213).

Against my above analysis, such an assessment is most surprising. The aspects pertaining to the foundations of IS-LM are now totally neglected. Patinkin ends up assuming that a single framework exists, which could be the vehicle for two distinct interpretations of Keynes, his interpretation in terms of unemployment disequilibrium and Modigliani's interpretation in terms of wage rigidity and unemployment equilibrium. If my above analysis is correct, Patinkin's remark makes no sense. It totally eschews what I view as the main difference between him and Modigliani, confirming that inventors of models can go astray when it comes to putting models in perspective. 19

Why did Patinkin as well as his contemporaries fail to realize the true nature of his contribution? The fact that IS-LM stemmed from the Marshallian tradition means that it was developed without the help of a fully specified general equilibrium theory. The absence of an identified Marshallian general equilibrium model can then explain why Patinkin did not perceive the Marshallian ascendancy of IS-LM. For him, as a general equilibrium model it was necessarily Walrasian (cf. De Vroey, this volume). Most of his contemporaries were actually of the same opinion (which moreover is still prevailing at present) that any model that was general equilibrium was automatically Walrasian. This was definitely the case for the early promoters of IS-LM. They believed that IS-LM was linked in some way to the Walrasian model, an idea that was explicitly put forward by Lawrence Klein ([1947] 1966, 56-57) in his Keynesian Revolution:

19. I believe the contention that economists can develop theoretical ideas without fully realizing their implications would not have seemed outrageous to Patinkin, who once wrote that it was "this personal experience of knowing, but not knowing - knowing something, but not realizing its 'obvious' implications for other problems with which I was concurrently dealing until a later point of time, an experience that I have had on other occasions as well-that has strongly influenced my subsequent work in the history of doctrines, especially that dealing with the discovery of the General Theory" (1995, 381-82). 
A problem which has never been adequately considered by Keynesians is the derivation of a theory in terms of communities of individuals and groups of commodities from a basic theory in terms of individuals and single commodities. In modern economic terminology this is the problem of passing from micro to macro economics, i.e., aggregation. ... The theories of individual behavior provide a complete set of inter-relationships within the economy; e.g., they give us the demand-and-supply relationships of every commodity in the system. This is the famous Walrasian system of general equilibrium.

This passage introduced Klein's presentation of the components of ISLM, showing that he considered IS-LM as a simplified version of the Walrasian system. The same view appears in Lange's founding contribution, "The Rate of Interest and the Optimum Propensity to Consume," which stated that the equation $Y=C+I$ corresponded "to the sum of the budget equations in the Walrasian system" (1938, 22-23). Modigliani's reference to the Walrasian system as the "only rigorous procedure" to "set up a system of equations describing the relation between the variable to be analyzed" on page 46 of his 1944 paper is a further example. However, all these economists hardly went further than these general statements, remaining unaware of the non-Walrasian character of their macro models. Only Patinkin systematically attempted to relate IS-LM and the Walrasian model. However, he overlooked the fact that the Walrasian foundation he was so eager to keep was absent from the other models.

\section{Conclusion}

I have shown that Patinkin's model is superior to Modigliani's 1944 ISLM model. Modigliani lacked an adequate method to deal with general equilibrium. In contrast, because of his Walrasian approach, Patinkin was able to complete, to correct, and to clarify the IS-LM model. However, in spite of its superiority, Patinkin's Walrasian recasting of the IS-LM did not replace Modigliani's model as the referential version of IS-LM. Money, Interest, and Prices played an important role in the teaching of economics at the graduate level, but when it came to textbooks, Modigliani's 1944 model prevailed (cf. Branson 1979 or Sargent 1987).

The fate of Patinkin's model becomes intelligible when considered from the viewpoint of Leijonhufvud's conception of history as forming a 
decision tree. In the history of IS-LM, Patinkin's work marked a methodological bifurcation, opening a route departing from the original conception of IS-LM associated with Hicks and Modigliani and which was Marshallian in spirit. Unfortunately, Patinkin himself did not realize the true nature of his contribution.

If Patinkin's option had no sequel in the 1960s, the route he opened was taken up later. In the 1970s, "disequilibrium" theorists (e.g., Barro and Grossman 1971) returned to the task of constructing a Keynesian model starting from the Walrasian model. This attempt was short-lived, as it was dethroned by the new classical revolution that marked the real takeoff of a purely Walrasian macroeconomics. The connection between this new bifurcation in the history of macroeconomics and Patinkin's work shall be the subject of further research.

\section{References}

Barro, R. J. 1974. Are Governments' Bonds Net Wealth? Journal of Political Economy 82:1095-117.

Barro, R. J., and H. I. Grossman. 1971. A General Disequilibrium Model of Income and Employment. American Economic Review 61:82-93.

Branson, W. H. 1979. Macroeconomic Theory and Policy. 2nd ed. New York: Harper \& Row.

Darity, W., and W. Young. 1995. IS-LM: An Inquest. HOPE 27:1-41.

D'Autume, A. 2000. L'essor de la macroéconomie. In La nouvelle histoire de la pensée économique, edited by A. Béraud and G. Faccarello. Paris: La Découverte.

De Vroey, M. 1999a. Keynes and the Marshall-Walras Divide. Journal of the History of Economic Thought 21:117-36.

. 1999b. The Marshallian Market and the Walrasian Economy: Two Incompatible Bedfellows. Scottish Journal of Political Economy 46:319-38.

. 2000. IS-LM à la Hicks versus IS-LM à la Modigliani. HOPE 32:293-316.

Gurley, J. G., and E. S. Shaw. 1960. Money in a Theory of Finance. Washington, D.C.: Brookings Institution.

Hicks, J. 1937. Mr. Keynes and the "Classics": A Suggested Interpretation. Econometrica 5:147-59.

Klein, L. [1947] 1966. The Keynesian Revolution. 2nd ed. New York: Macmillan.

Kouri, P. J. K. 1986. Franco Modigliani's Contribution to Economics. Scandinavian Journal of Economics 88:335-53.

Lange, O. 1938. The Rate of Interest and the Optimum Propensity to Consume. Economica 5:12-32.

1942. Say's Law: A Restatement and Criticism. In Studies in Mathematical Economics and Econometrics, edited by O. Lange, F. McIntyre, and T. O. Yntema. Chicago: University of Chicago Press. 
Leijonhufvud, A. 1994. Hicks, Keynes, and Marshall. In The Legacy of Hicks: His Contributions to Economic Analysis, edited by H. Hagemann and O. F. Hamouda. London: Routledge.

Lucas, R. E., Jr. [1980] 1981. Methods and Problems in Business Cycle Theory. In Studies in Business Cycle Theory. Cambridge: MIT Press.

Metzler, L. A. 1951. Wealth, Saving, and the Rate of Interest. Journal of Political Economy 59:93-116.

Modigliani, F. 1944. Liquidity Preference and the Theory of Interest and Money. Econometrica 12:45-88.

1963. The Monetary Mechanism and Its Interaction with Real Phenomena. Review of Economics and Statistics 45.1 (part 2, supplement): 79-107.

. 1987. Comments on "1944, 1963, and 1985." In Macroeconomics and Finance: Essays in Honor of Franco Modigliani, edited by R. Dornbusch, S. Fisher, and J. Bossons. Cambridge: MIT Press.

Patinkin, D. 1947. On the Consistency of Economic Models: A Theory of Involuntary Unemployment. $\mathrm{PhD}$ diss., University of Chicago.

_.1947-48. Correspondence with Franco Modigliani. Box DPP29, Don Patinkin Papers. Rare Book, Manuscript, and Special Collections Library, Duke University.

. 1948. Price Flexibility and Full Employment. American Economic Review 38:543-64.

. 1949a. The Indeterminacy of Absolute Prices in Classical Economic Theory. Econometrica 17:1-27.

. 1949b. Involuntary Unemployment and the Keynesian Supply Function. Economic Journal 59:361-83.

1954. Keynesian Economics and the Quantity Theory. In Post Keynesian Economics, edited by K. K. Kurihara. New Brunswick, N.J: Rutgers University Press.

1956. Money, Interest, and Prices. Evanston, Ill.: Row, Peterson.

1958. Liquidity Preference and Loanable Funds: Stocks and Flow Analysis. Economica 25:300-318.

1961. Financial Intermediaries and the Logical Structure of Monetary Theory: A Review Article. American Economic Review 51:95-116.

— . [1965] 1972. La monnaie, l'intérêt et les prix. Paris: Presses Universitaires de France.

. 1974. The Role of the "Liquidity Trap" in Keynesian Economics. Banca Nazionale del Lavoro Quarterly Review 108:3-11.

. 1976. Keynes' Monetary Thought: A Study of Its Development. HOPE $8.1: 1-150$.

. 1990a. In Defense of IS-LM. Banca Nazionale del Lavoro Quarterly Review 43:119-31.

. 1990b. On Different Interpretations of the General Theory. Journal of Monetary Economics 26:205-43. 


\section{Goulven Rubin}

1995. The Training of an Economist. Banca Nazionale del Lavoro Quarterly Review 195:359-95.

Rubin, G. 2002a. From Equilibrium to Disequilibrium: The Genesis of Don Patinkin's Interpretation of the Keynesian Theory. European Journal of History of Economic Thought 9:205-25.

— 2002b. La contribution de Don Patinkin à la "synthèse néoclassique": Genèse et portée. $\mathrm{PhD}$ diss., University of Paris X-Nanterre.

Sargent, T. J. 1987. Macroeconomic Theory. 2nd ed. San Diego: Academic Press.

Weintraub, E. R. 1979. Microfoundations. Cambridge: Cambridge University Press. 
Copyright of History of Political Economy is the property of Duke University Press and its content may not be copied or emailed to multiple sites or posted to a listserv without the copyright holder's express written permission. However, users may print, download, or email articles for individual use. 